\title{
PENGENALAN DASAR AKUNTANSI SERTA PERANAN PROFESI BAGI MASA DEPAN SISWA/I SMA KRISTEN ALMASIH
}

\author{
Syanti Dewi ${ }^{1}$ dan Anastasya ${ }^{2}$ \\ ${ }^{1}$ Jurusan Akuntansi, Universitas Tarumanagara Jakarta \\ Email: syantid@untar.ac.id \\ ${ }^{2}$ Jurusan Akuntansi, Universitas Tarumanagara Jakarta \\ Email: nanascy0107@gmail.com
}

\begin{abstract}
The basics of accounting are very important for someone who will do business. Therefore, we conduct counseling to students, as well as motivate them about choosing a career related to the science they are pursuing for their future in choosing which major and university to go to. Since the 2020 Pandemic, all schools use an online learning system, so we want to provide counseling to high school students about the basics of accounting, as well as provide information about professions that can be taken into consideration after graduating from school. As prospective students, they must know a very promising profession for their future. This introduction can be a factor in their career choice. This is what drives us, in introducing a promising profession for the future. Then a follow-up was carried out by making a statement of cooperation from Mr. Joseph Setiawan as the Principal of the Almasih Christian High School. This activity was carried out through zoom, followed by high school students majoring in science and social studies, which could provide knowledge and insight for them. The results of this activity can increase the intention of school students to continue to college, coupled with support from schools and parents. So that it can improve the quality of human resources to become useful individuals for the nation and state. The results achieved in this activity encourage their interest to enter college in the accounting field.
\end{abstract}

Keywords: accounting, profession

Dasar-dasar akuntansi sangat penting bagi seseorang yang akan melakukan usaha. Oleh karena itu, kami melakukan penyuluhan kepada siswa dan siswi, serta metivasi mereka tentang pemilihan karir yang berhubungan dengan ilmu yang ditekuni bagi masa depan mereka dalam memilih jurusan dan universitas mana yang akan dituju. Sejak Pandemi tahun 2020, semua sekolah menggunakan sistem pembelajaran online, sehingga kami ingin memberikan penyuluhan kepada siswa-siswi SMA mengenai dasar-dasar akuntansi, serta memberikan informasi mengenai profesi yang dapat menjadi bahan pertimbangan setelah lulus dari sekolah. Sebagai calon mahasiswa, mereka harus mengenal profesi yang sangat menjanjikan bagi masa depan mereka. Pengenalan ini dapat menjadi salah satu faktor dalam pemilihan karir mereka. Hal inilah yang mendorong kami, dalam memperkenalkan profesi yang menjanjikan buat masa depan. Maka dilakukan tindak lanjut dengan membuat surat pernyataan kerjasama dari Bapak Joseph Setiawan selaku Kepala Sekolah Menengah Atas Kristen Almasih. Kegiatan ini dilakukan melalui zoom dengan diikuti oleh siswa dan siswi SMA jurusan IPA dan IPS, yang dapat memberikan pengetahuan dan wawasan bagi mereka. Hasil kegiatan ini dapat meningkatkan niat siswa-siswi sekolah untuk melanjutkan ke perguruan tinggi, ditambah dengan dukungan dari sekolah dan orang tua. Sehingga dapat meningkatkan kualitas sumber daya manusia menjadi pribadi yang berguna bagi bangsa dan negara. Hasil yang dicapai dalam kegiatan ini, mendorong minat mereka untuk masuk kuliah di bidang akuntansi.

Kata kunci: akuntansi, profesi

\section{PENDAHULUAN}

Akuntansi sangat penting bagi kehidupan sehari-hari manusia. Sejak kita mengenal penerimaan dan pengeluaran uang kita, seperti menabung dan membelanjakan uang yang kita punyai, artinya kita dapat mengendalikan keuangan sendiri, serta menerapkan kegiatan akuntansi, yang sangat membantu mengendalikan keuangan. Menurut Hans Kartikahadi, et al. (2016), suatu informasi keuangan penting yang mempunyai tujuan menghasilkan dan melaporkan informasi yang berguna dan relevan untuk berbagai pihak seperti pihak internal maupun eksternal, disebut akuntansi. 
Sehingga dapat disimpulkan, akuntansi adalah sebuah proses mengidentifikasi, mencatat, dan melaporkan informasi keuangan kepada pihak yang berkepentingan sehingga menghasilkan sebuah laporan keuangan yang berguna bagi pelaku usaha.

Pencatatan transaksi keuangan sangat penting bagi semua orang terutama para pengusaha dalam menjalankan usahanya. Putra dan Arizona (2016), mengungkapkan bahwa banyak pengusaha yang menutup usahanya, hal ini dikarenakan mereka tidak mempunyai pengetahuan akuntansi sama sekali, sehingga sulit membuat suatu keputusan. Sehingga banyak dari pengusaha yang tidak dapat memisahkan antara uang pribadi dan uang yang berasal dari transaksi usaha. Hal ini yang menyebabkan laba atau keuntungan menjadi tidak jelas, serta pengeluaran uang untuk modal usaha. Setiap pengusaha harus memikirkan kelangsungan usahanya (going concern) dalam menjalankan sebuah bisnis supaya berkembang dan maju. Salah satu tolak ukur untuk menjaga kelangsungan sebuah usaha adalah pengambilan keputusan investasi yang tepat. Dalam pengambilan keputusan, diperlukan pengetahuan tentang akuntansi dan pajak. Sehingga dapat disimpulkan bahwa semua orang harus mengerti akuntansi setidaknya dasar-dasarnya, seperti memahami saldo akun, saldo, membuat jurnal dan lain-lain.

Adanya pembekalan dasar-dasar akuntansi, bagi para siswa supaya dapat memilih jalur pendidikan yang akan ditempuh setelah mereka lulus dari sekolah SMA. Setelah mereka memilih jurusan yang cocok dalam pengembangan karir dan mudah mendapatkan pekerjaan selama kondisi pandemi covid-19. Karir disebut sebagai suatu keahlian profesional individu dalam suatu bidang dari kontribusi suatu organisasi dan menjadi pengalaman kerja (Nurmastadiyah, 2009 dalam Azizah dan Juliyanti, 2021). Apabila mereka memilih karir konsultan dan akuntan, menurut Suyono (2014) profesi ini memberikan peluang untuk mendapatkan pekerjaan yang menantang dan bervariasi karena dapat ditugaskan di berbagai tempat dan perusahaan yang memiliki bidang usaha dan kondisi yang berbeda. Sedangkan menurut Bachtiar (2002), Aprilyan (2011) dalam Suyono (2014), profesi yang paling termahal adalah profesi akuntan publik. Profesi ini bisa menjadi profesi termahal karena yang menjadi sumber pendapatan terbesar dari AP adalah bukan saja berasal dari jasa audit, melainkan jasa konsultasi manajemen, dan jasa lainnya sesuai dengan ketentuan Undang-Undang Akuntan Publik. Sedangkan untuk profesi konsultan pajak, juga sangat menjanjikan bagi masa depan, karena selama pandemi banyak peraturan-peraturan pajak yang terbaru dalam menghitung pajak badan maupun perorangan. Hal ini yang membuat, semua profesi ini menjadi prospek peluang kerja, dan peminatan siswa siswi ke jurusan ke ekonomi dan bisnis. Menurut Ikbal (2011) dalam Nay et al (2021), pendidikan akuntansi dapat menghasilkan akuntan dan konsultan yang profesional sesuai dengan evolusi kebutuhan masa depan akan jasa akuntansi. Pendidikan tinggi akuntansi, jika tidak bisa menghasilkan profesionalisme sebagai akuntan tidak akan laku di dunia kerja. Hal ini membuat akuntansi memainkan peran penting dalam perekonomian Indonesia karena keputusan keuangan harus didasarkan pada pengetahuan akuntansi. Laporan keuangan tahunan disusun sesuai dengan prinsip akuntansi yang berlaku umum.

Sejak pandemi covid-19, banyak sekali memberikan dampak yang sangat signifikan terutama sektor ekonomi, hal ini dirasakan banyak perusahaan yang memberhentikan karyawan dengan alasan pemberlakuan pembatasan kegiatan masyarakat, dan karyawan diharapakan untuk bekerja dari rumah. Sehingga di masa kini, kebutuhan akan pengetahuan tentang akuntansi sangatlah penting bagi semua lapisan masyarakat. Menurut Farwitawati dan Masirun (2021), pendidikan sangat penting dan menjadi hal yang paling mendasar dalam segala segi aspek kehidupan manusia. Melalui pendidikan, manusia dapat menjadi cerdas dan mempunyai banyak pengetahuan dan ilmu, serta di tangan pendidikan pula manusia yang awalnya pasif menjadi kreatif. Maka dari itu, disadari perlunya pengetahuan tentang dasar akuntansi bagi siswa siswi sekolah Sekolah Menengah Atas (SMA) Kristen Almasih sebagai calon mahasiswa S1 Akuntansi, yang sudah selayaknya mendapatkan pengetahuan tentang dasar-dasar akuntansi. 
Menurut Suyatmini et al (2018), menyatakan bahwa salah satu ilmu pengetahuan yang bermanfaat bagi kehidupan manusia adalah akuntansi. Dalam kehidupan sehari-hari, kita dapat mengaplikasikan ilmu akuntansi, seperti mengatur uang jajan anak sekolah agar bisa cukup untuk jangka waktu tertentu atau mengalokasikan uang tersebut sesuai dengan kebutuhan belanja yang sangat diharapkan.

Sejak pandemi, kegiatan pembelajaran dilakukan secara online, maka kami juga memberikan penyajian tentang pengetahuan dasar akuntansi secara daring. Materi pembelajaran ini dapat menjadi bekal mereka di kemudian hari. Sehingga apabila ada yang belum memahami dasardasar akuntansi, serta peranan profesi bagi masa depan mereka. Kami menyajikan secara materi semenarik mungkin, supaya dengan adanya penyuluhan tentang pengetahuan ini, dapat memotivasi mereka dalam menumbuhkan minat untuk berkarir di bidang akuntansi dan pajak. Permasalahan mitra kami adalah pengetahuan tentang dasar-dasar akuntansi, memberikan pengetahuan tentang peranan profesi atau karir yang sangat menjanjikan untuk masa depan. Target luaran kegiatan pengabdian masyarakat ini adalah membuka wawasan para siswa SMA Kristen Almasih untuk memahami dasar-dasar akuntansi serta profesi yang bisa diambil setelah mereka lulus kuliah.

\section{METODE PELAKSANAAN PKM}

Kegiatan penyuluhan ini dikemas dalam bentuk ceramah dan tanya jawab secara online dengan menggunakan zoom, serta ada kuis dan penyebaran angket melalui google form untuk mendapat masukkan dari peserta. Pada waktu sosialisasi dilakukan, seluruh peserta wajib menggunakan zoom dengan link yang akan diberikan. Materi ceramah disajikan dalam bentuk power point. Sesi tanya jawab disediakan untuk memperjelas materi bahasan, serta ada sesi kuis agar menarik minat siswa, dan mendapat masukkan dari peserta terhadap penyuluhan ini. Pihak sekolah membantu menyiapkan murid-murid yang akan mengikuti penyuluhan, serta menentukan tanggal dan waktu penyelenggaraan yang diusahakan pada jam sekolah.

Kegiatan pengabdian kepada masyarakat ini yang dilaksanakan dilakukan dalam beberapa tahap, yaitu tahap persiapan sosialisasi, dan tahap pertemuan untuk penyuluhan kepada siswa siswi. Tahap persiapan dilaksanakan dengan kunjungan ke tempat mitra, untuk membicarakan mengenai masalah atau hal-hal apa saja yang menjadi kendala mitra, dan aplikasi yang digunakan. Tahap pertemuan membahas tentang materi yang akan disajikan.

\section{HASIL DAN PEMBAHASAN}

Dalam mengwujudkan keinginan untuk mendapatkan kehidupan yang layak, setiap orang ingin berwiraswasta yang artinya mempunyai usaha yang maju. Dalam melakukan usaha, setiap orang mengalami kendala dan tidak gampang menjalankannya. Sehingga dibutuhkan skill, bakat, ilmu pengetahuan, agar kelansungan usaha berjalan dengan lancar. Ilmu pengetahuan yang harus dimiliki oleh seorang wiraswasta, adalah ilmu akuntansi. Akuntansi adalah suatu proses pencatatan, pengklasifikasian, pengikhtisaran dan pelaporan transaksi bisnis yang mempunyai nilai moneter dan mempersentasikan hasilnya (Agoes dan Winoto, 2019). Menurut Anisa (2017), dasar-dasar akuntansi menjadi salah satu mata pelajaran yang ada dalam bidang kompetensi keahlian akuntansi. Hasil definisi ini, dapat disimpulkan bahwa aktivitas akuntansi merupakan sistem informasi yang mencakup tiga aktivitas, yaitu mengidentifikasi, mencatat dan mengkomunikasikan. Mengidentifikasi adalah menetapkan kejadian ekonomi atau transaksi bisnis dalam perusahaan. Mencatat artinya mencatat transaksi-transaksi sehari-hari ke dalam catatan akuntansi, sampai menghasilkan laporan keuangan. Mengkomunikasikan adalah menyampaikan laporan keuangan kepada pihak pengguna laporan untuk mengambil suatu keputusan bagi kelangsungan usahanya. Pihak pengguna terdiri dari pihak eksternal maupun internal, seperti direksi, pemegang saham, investor, instansi pemerintah, dan masyakarat. 
Setidaknya dengan adanya pembekalan ilmu tersebut, seorang wiraswasta, mengerti tentang jurnal-jurnal akuntansi yang berkaitan dengan usahanya. Kalau usaha jasa, dia harus mengerti tentang akun-akun yang terdapat di jasa tersebut, sedangkan untuk usaha dagang, harus mengerti tentang akun usaha dagang. Sehingga dengan adanya bekal ilmu tersebut, dapat mengetahui laba atau rugi usaha dia secara keseluruhan. Kegiatan ini dilakukan sebagai bentuk partisipasi kami dalam memberikan penyuluhan pentingnya dasar-dasar akuntansi, karena dengan adanya pengetahuan akuntansi, kita dapat menjalankan bisnis dengan baik. Tanpa adanya pengetahuan tentang akuntansi, bisnis tidak berjalan dengan baik. Siswa siswi dalam mempelajari konsep dasar akuntansi, adalah mulai dari pengertian, persamaan dasar akuntansi, serta menganalisis transaksi. Hal ini merupakan faktor dasar, supaya para siswa tertarik dalam pelajaran akuntansi. Pada era globalisasi saat ini, masyarakat Indonesia dituntut untuk menjadi masyarakat yang berpendidikan, untuk menguasai berbagai macam ilmu dan pengetahuan serta meningkatkan kemampuan dalam segi bidang aspek. Hal yang dapat memberikan dan meningkatkan kemampuan adalah dengan bersekolah atau masuk suatu lembaga pendidikan. Sangat diharapkan, untuk ke depannya pemerintah dapat mengupayakan peningkatan anggaran dengan melakukan upaya peningkatan efisiensi dalam sistem pendidikan, strukturisasi anggaran, dan prioritas alokasi anggaran yang memacu prestasi belajar siswa, sehingga akhirnya dapat dicapai peningkatan sumber daya manusia Indonesia lewat pendidikan. Seiiring dengan perkembangan ilmu pengetahuan maupun teknologi informasi yang berkembang sangat pesat. Dengan adanya pengetahuan tentang dasar-dasar akuntansi, maka para siswa dan siswi mempunyai bekal ilmu yang akan berguna kedepannya terutama dalam bidang wirausaha. Oleh karena itu, peran penting pelajar sebagai generasi muda tersebut harus dibekali dengan sikap integritas yang tinggi, karena integritas saat ini merupakan hal yang sangat mendasar bagi mereka untuk melanjutkan pembangunan yang bermartabat.

Menurut Walgito (2005) dalam Alfan (2014), supaya seseorang dapat bekerja dengan baik, senang dan tekun, diperlukan bimbingan karir supaya dapat menyesuaikan dengan tuntutan dari jabatan atau pekerjaan, dengan apa yang ada dalam diri individu itu sendiri. Hal tersebut diperlukan seorang individu, supaya mendapatkan pekerjaan sesuai yang diharapkan dengan kemampuan yang dimilikinya. Apabila seseorang bekerja sesuai kemampuan dan minatnya, serta mengerjakan dengan hati yang senang dan gembira, maka dapat menghasilkan tujuan yang akan dicapai. Tetapi sebaliknya, jika bekerja tidak sesuai dengan kemampuan yang dimilikinya, maka dapat dipastikan akan kurang bergairah dalam bekerja, tidak senang serta malas. Havighurst membahas perkembangan karir sebagai proses seumur hidup yang terdiri atas enam tahapan yang dimulai sejak masa kanak-kanak hingga berusia senja (Gibson \& Mitchell, 2011 dalam Juliyanti dan Azizah, 2021). Berdasarkan teori ini, kami melakukan penyuluhan tentang profesi yang sangat menarik bagi masa depan siswa dan siswi sekolah dalam melanjutkan ke perguruan tinggi.

Menurut Slameto (2010) dalam Arifianto dan Sukanti (2014), menyatakan bahwa suatu rasa lebih suka dan rasa ketertarikan pada suatu hal atau aktivitas, tanpa ada yang menyuruh disebut minat. Sehingga dapat disimpulkan, jika seseorang mempunyai minat atas suatu aktivitas akan mengerjakan aktivitas itu secara konsisten serta senang, dan didasarkan rasa suka serta tidak ada paksaan dari pihak luar. Seorang individu mempunyai keyakinan, kemampuan, keterampilan, serta pengetahuan yang dimilikinya sehingga berkaitan dengan karir atau profesi yang akan dipilihnya.

Profesi adalah pekerjaan yang dilakukan seseorang karena pelatihan dan penguasaan khusus, sehingga mempunyai karakteristik sendiri yang membedakannya dari pekerjaan lainnya. Profesi yang disampaikan dalam penyuluhan ini adalah profesi akuntan publik dan konsultan pajak, yang sampai detik ini masih diminati, karena dapat dengan mudah mendapatkan pekerjaan setelah lulus kuliah. Hal inilah yang memacu kami, untuk memberikan materi tersebut kepada 
siswa dan siswi sekolah menengah atas. Materi tersebut dapat membantu supaya pengetahuan mereka bertambah, tentang profesi yang banyak diiminati. Materi tersebut memaparkan tentang Certified Public Accountant di Indonesia. Seorang Akuntan Publik adalah orang yang telah memperoleh atau mendapatkan izin dari Kementerian Keuangan untuk memberikan jasa audit kepada entitas. Profesi ini yang dapat memberikan peluang untuk mendapatkan pekerjaan yang menantang dan bervariasi, sehingga dapat ditugaskan di berbagai tempat dan perusahaan yang memiliki usaha yang berbeda-beda, seperti manufaktur, usaha pembiayaan, bank dan lain-lain. Akuntan publik sebagai bagian dari profesi akuntansi memiliki peran yang sangat strategis dalam dunia bisnis. Hal ini didasarkan atas pertimbangan bahwa hanya akuntan publik yang memiliki kewenangan untuk memberikan opini atas laporan keuangan klien atau entitas (Suyono, 2014). Asosiasi akuntan publik yang terdapat di Indonesia adalah Institut Akuntan Publik Indonesia. Seluruh akuntan publik yang terdaftar wajib mengikuti pendidikan professional berkelanjutan (PPL) setiap tahunnya. Gambaran ini yang kami sajikan, sehingga mereka dapat memilih karir atau profesi yang sangat menjanjikan bagi masa depan, terutama para siswa dan siswi SMA yang akan memilih jurusan akuntansi dan bisnis.

Selain profesi ini, ada profesi lain yang juga banyak diminati yaitu tax consultant. Seorang konsultan pajak berperan sebagai agen perpajakan dan juga perantara antara WP dan fiskus (aparatur perpajakan). Posisi dalam profesi ini berada dalam dua kepentingan yang berbeda, yaitu kepentingan negara dalam meningkatkan jumlah penerimaan negara serta kepentingan klien terutama entitas dalam meminimalkan beban pajak (Inside Tax, 2013 dalam Kusuma et al, 2016). Fiskus disini sering disebut sebagai petugas pajak. Profesi yang pekerjaan sebagai penghubung antara otoritas pajak dan wajib pajak disebut konsultan pajak. Sedangkan otoritas membutuhkan informasi dari wajib pajak, tetapi mereka perlu kenyamanan dalam melaksanakan hak dan kewajiban pajaknya. Wajib pajak yang baik dinilai berdasarkan kepatuhannya terhadap kewajiban membayar pajak serta melaporkan pajak secara tepat waktu. Sedangkan petugas pajak dinilai dari kinerjanya berdasarkan pencapaian target penerimaan pajak (Kusuma et al, 2016).

Berdasarkan penyuluhan ini, hasil yang kami dapat selama pelatihan berlangsung, terdapat banyak minat dari siswa dan siswi SMA untuk melanjutkan ke perguruan tinggi terutama jurusan akuntansi ataupun manajemen. Hal ini dikarenakan, pekerjaan mudah didapat setelah mereka lulus sekolah menengah atas dan kuliah, serta berguna untuk pengembangan karir mereka di masa yang akan datang. Hasil pelatihan yang diadakan selama kegiatan berlangsung, dapat dilihat di gambar 1 (satu) dan 2 (dua).

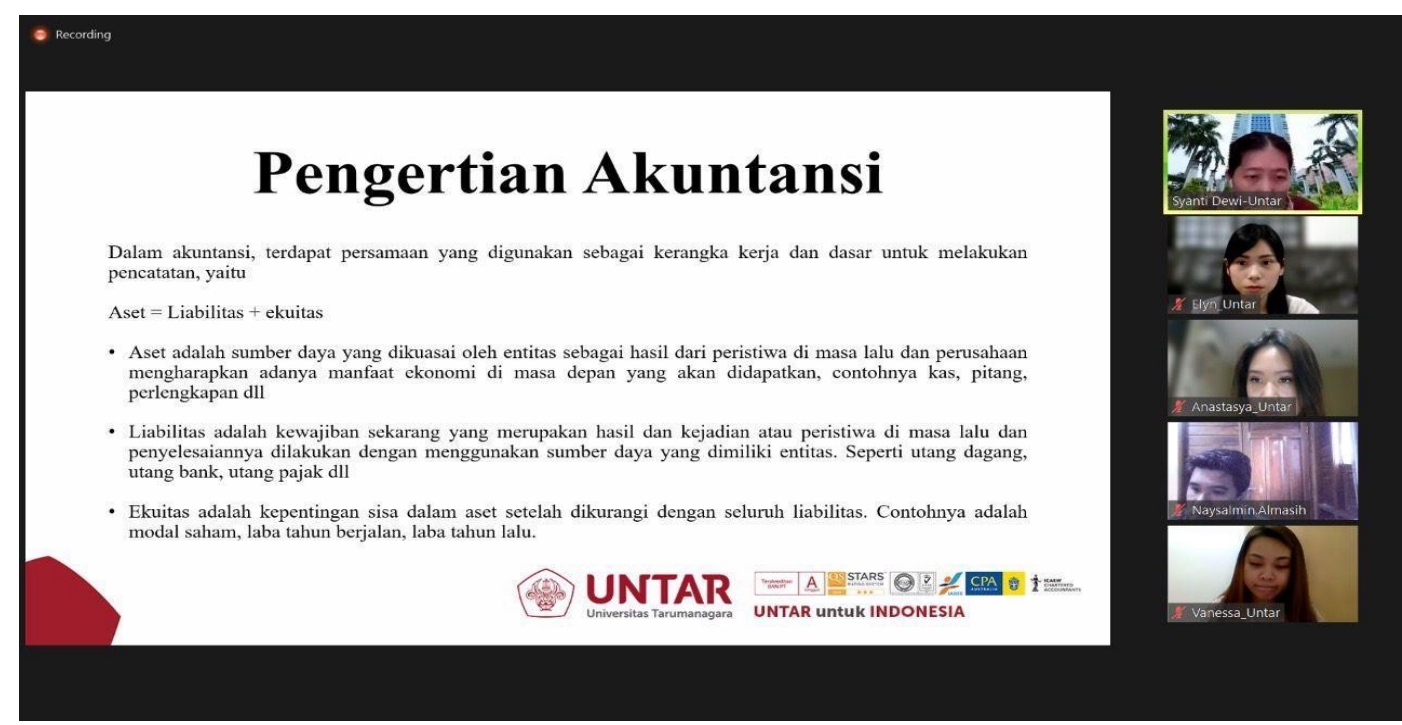

Gambar 1 Sesi pelatihan 


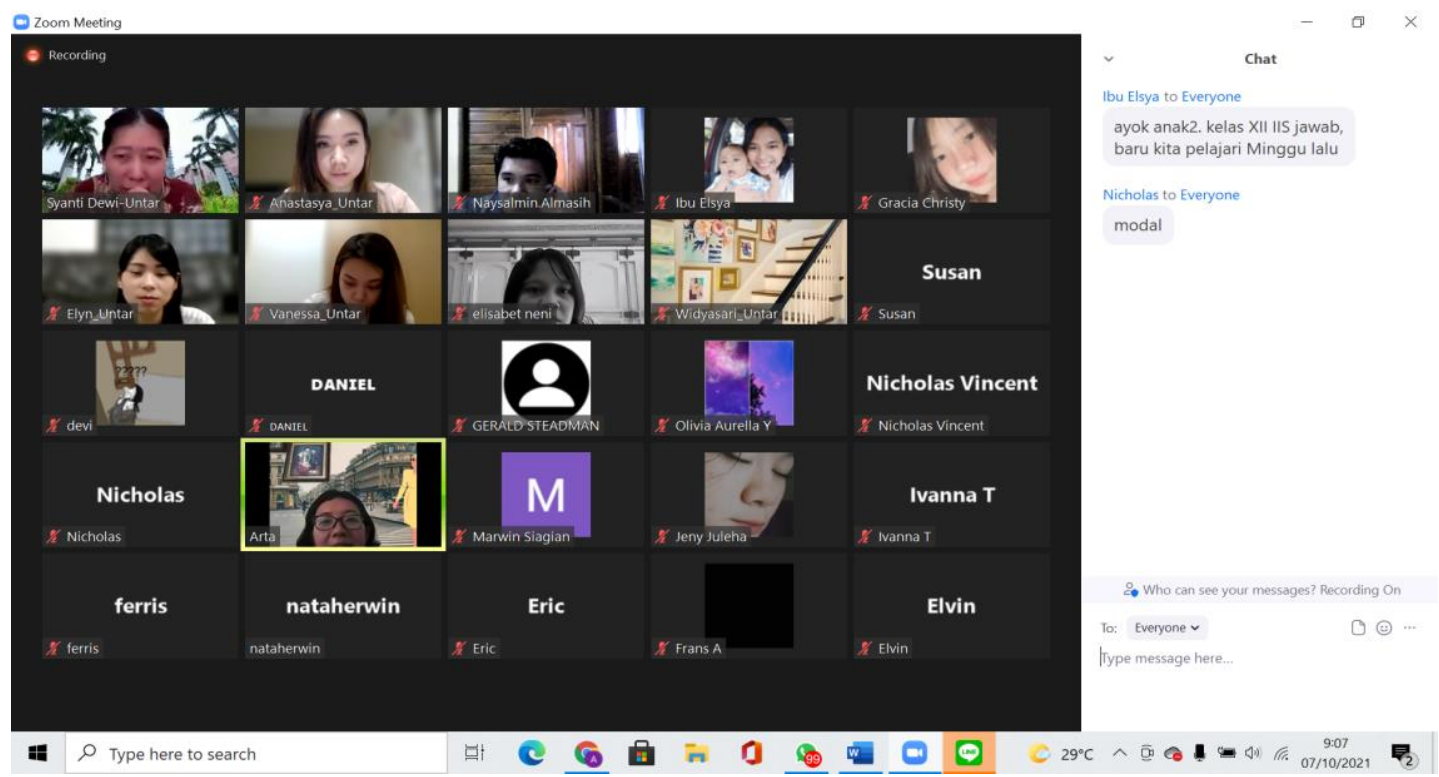

Gambar 2. Sesi tanya jawab dan kuis

\section{KESIMPULAN DAN SARAN}

Berdasakan hasil pembahasan, banyak peserta mengerti tentang dasar-dasar akuntansi seperti membuat jurnal dari perusahaan dagang ataupun perusahaan jasa. Hal ini menambah wawasan dari peserta didik, serta guru dan bapak kepala sekolah yang hadir di kegiatan ini. Peserta didik lebih tertarik dengan pembahasan mengenai profesi atau karir yang sangat menjanjikan buat masa depan mereka. Kegiatan ini juga meningkatkan minat peserta didik SMA Kristen Almasih untuk studi lanjut ke perguruan tinggi, dengan dukungan dari orang tua serta guru-guru disekolah. Sarannya, kami akan mengadakan pengabdian masyarkat ini bukan hanya materi atau topik ini, melainkan topik yang menarik agar peserta didik dapat menambah pengetahuan tentang standar akuntansi yang ada di Indonesia.

\section{Ucapan Terima Kasih}

Saya mengucapkan terima kasih kepada bapak Joseph Setiawan, S.T selaku kepala sekolah menengah atas, serta ibu Arta sebagai guru disekolah SMA Kristen Almasih, guru-guru lain yang hadir di kegiatan ini menemani peserta didik. Selain itu, mengucapkan terima kasih kepada Lembaga Penelitian dan Pengabdian Kepada Masyarakat Universitas Tarumanagara, serta asisten pelaksana PKM yang mendukung pelatihan ini.

\section{REFERENSI}

Arifianto, Fajar dan Sukanti (2014). Pengaruh Motivasi Diri dan Persepsi Mengenai Profesi Akuntan PublikTerhadap Minat Menjadi Akuntan Publik Pada Mahasiswa Prodi Akuntansi Fakultas Ekonomi Universitas Negeri Yogyakarta. Jurnal Nominal. Volume III No.2.

Annisa, Vera (2017). Pengaruh Self Efficacy Terhadap Hasil Belanjar Dasar-Dasar Akuntansi di SMKN 1 Pontianak. Jurnal Pendidikan dan Pembelajaran Khatulistiwa. Diakses dari https://jurnal.untan.ac.id/index.php/jpdpb/issue/view/777

Azizah, Nur. dan Juliyanti, Rina. (2021). Motivasi Pilihan Karir Bagi Remaja Pada Masa Pandemi Covid-19. Diakses dari http://journal.umpalangkaraya.ac.id/index.php/anterior. Kartihadi, Hans. dkk. (2016). Akuntansi Keuangan Berdasarkan SAK Berbasis IFRS. Jakarta: IAI. 


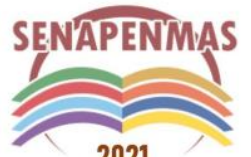

2021
Seminar Nasional Hasil Penelitian dan Pengabdian Kepada Masyarakat 2021

Pengembangan Ekonomi Bangsa Melalui Inovasi Digital Hasil Penelitian dan Pengabdian Kepada Masyarakat Jakarta, 21 Oktober 2021

Putra, I Putu Mega Juli Semara dan Arizona, I Putu Edy (2016). Pengaruh Pengetahuan Akuntansi dan Jiwa Kewirausahaan Terhadap Penggunaan Informasi Akuntansi Dalam Pengambilan Keputusan Investasi. Seminar Nasional. Lembaga Penelitian dan Pemberdayaan Masyarakat (LPPM) Unmas Denpasar 
Seminar Nasional Hasil Penelitian dan Pengabdian Kepada Masyarakat 2021

Pengembangan Ekonomi Bangsa Melalui Inovasi Digital Hasil Penelitian dan

Pengabdian Kepada Masyarakat

Jakarta, 21 Oktober 2021

(halaman kosong) 